\title{
The study of bacteria in biopsies from Slovak colorectal adenoma and carcinoma patients
}

\author{
L. WACHSMANNOVA ${ }^{1, *}$, J. MAJEK ${ }^{2}$, V. ZAJAC ${ }^{1}$, V. STEVURKOVA ${ }^{1}$, S. CIERNIKOVA ${ }^{1}$ \\ ${ }^{1}$ Department of Genetics, Cancer Research Institute BMC, Slovak Academy of Sciences, Bratislava, Slovakia; ${ }^{2}$ Department of Gastroenterology, \\ National Cancer Institute, Bratislava, Slovakia \\ *Correspondence: exonlmat@savba.sk
}

Received January 17, 2018 / Accepted March 9, 2018

\begin{abstract}
The development of colorectal cancer is affected by many factors, especially the intestinal microbiota. However, precise knowledge of bacterial communities associated with the mucosa in various parts of the colon is limited. Herein, we applied the gentamicin protection assay and detected the presence of intracellular bacteria in colorectal biopsies from Slovak patients with colorectal adenoma and carcinoma, and we compared this with healthy controls. The ENTEROtest 24 and MALDI-TOF mass spectrometry identified the cultivated bacteria and results revealed the presence of intracellularly localized Escherichia coli, Proteus mirabilis and Proteus vulgaris in patients with colorectal adenomas and carcinomas. In addition to these species, Klebsiella pneumoniae, Pseudomonas aeruginosa, Enterococcus faecalis and Bacillus cereus were identified in colorectal biopsies, but these were extracellular. The marked increase in relative abundance of intracellular E. coli in patients with colorectal adenomas and carcinomas was statistically significant compared to controls, and our preliminary data supports E. coli's role as a pro-oncogenic pathogen.
\end{abstract}

Key words: colorectal cancer, Escherichia coli, intracellular bacteria, gentamicin protection assay

Colon microflora is a very complex system hosting several billion bacteria and these perform a multitude of functions. Microbes are major actors in biological environments and it is estimated that approximately $16 \%$ of global cancers are caused by microbes. Moreover several liver and gastrointestinal tract cancers are clearly identified as microberelated [1]. Important mechanisms bacterial agents employ to induce carcinogenesis include chronic infection, immune evasion and immune suppression [2].

Several studies identifying bacterial composition in healthy individuals and patients confirmed that the constitution and structure of intestinal microflora can lead to development of colorectal adenomas [3, 4]. 5] In addition to showing increased microbial diversity in the tumor area, Burns et al.[5] also described enrichment in virulenceassociated bacterial genes in the tumor micro-environment [5]. Organisms inducing asymptomatic but chronic inflammatory response in the colon increase individual susceptibility to colorectal cancer (CRC) [6].

While pathogenic Escherichia coli is linked to chronic infections of the colon and increased risk of colon cancer [7], the non-pathogenic E. coli major constituent of human aerobic flora hinder detection of pathogenic strains [8]. Bacterial adhesion, especially to dysplastic mucosa lacking an overlying mucus coat, has the potential to induce epithelial cell changes which promote cancer development [9]. Moreover, increased E. coli adherence and invasion has been reported in patients with both CRC and Crohn's disease [7].

However, distinction is necessary between indigenous 'bacteria drivers' able to drive epithelial DNA damage, and therefore able to promote colonic tumorigenesis, and the intestinal niche alterations that favor inhibition or proliferation of tumour growth [10]. Species such as Bacteroides, Shigella, Citrobacter, Salmonella and Escherichia may be considered bacteria drivers which are more abundant in the early stages of colorectal cancer (including adenomas) but disappear from cancerous tissue as they are replaced by passenger bacteria. These passenger bacteria can include Fusobacterium spp. [11], Streptococcus gallolyticus subsp. Gallolyticus, Clostridium septicum, Coriobacteriaceae and the Roseburia and Faecalibacterium genera [12]. These bacteria have a growth advantage in the tumor microenvironment.

The bacterial driver aspect of the driver-passenger model is related to the 'Alpha-bug' hypothesis proposed by Sears and 
Pardoll [13]. This hypothesis states that certain micro-biome members which possess unique virulence traits - bacteria that we term Alpha-bugs - are not only directly pro-oncogenic but are capable of remodeling the colonic bacterial community to one that enhances and further promotes Alpha-bug induction of mucosal immune responses and colonic epithelial cells changes; thus resulting in colon cancer [13]. Alphabugs may enhance carcinogenesis by selectively "crowding out" cancer-protective microbial species. While this hypothesis posits that drivers persistently colonize the developing tumour, the driver-passenger model proposes that they are mainly present in the initial stages of the disease and are later out-competed by passengers [12].

The aim of our study is detection and identification of intracellular bacteria in colorectal biopsies from Slovak patients with colorectal adenoma and carcinoma and to compare it with healthy controls. Bacterial invasion is the process by which invasive bacteria induce their own phagocytosis into eukaryotic cells which are normally non-phagocytic. Further, signal transduction pathways and host cell cytoskeleton are common bacteria virulence factor targets because these are involved in bacterial attachment to the cell surface and entry into cells $[14,15]$.

\section{Patients and methods}

Biopsy sample collection. Colorectal biopsies were collected at the National Cancer Institute, Bratislava, Slovakia, with prior approval of patient informed consent and the ethics committee. Exclusion criteria were ongoing antibiotic usage and completed neo-adjuvant chemo-radiotherapy. Twenty-nine patients underwent colonoscopy for screening or staging of colorectal malignancies and between two and six colonoscopic biopsy specimens from each patient were analyzed. Whenever possible, biopsy specimens were taken from both tumorous and normal mucosa.

Gentamicin-protection assay. The gentamicin protection assay (GPA) is based on the resistance of internalized bacteria to gentamicin because gentamicin is impermeable to mammalian cells and therefore kills only extracellular bacteria. Biopsy specimens were placed in $0.5 \mathrm{~mL}$ of $0.016 \%$ dithiothreitol solution for 15 minutes to deprive them of mucus. Each biopsy specimen was cut into two or three pieces. One piece was placed in physiological saline and the second in physiological saline with gentamicin at a concentration of $50 \mathrm{mg} / \mathrm{L}$ and incubated for 30 minutes. After incubation, each was placed in $0.5 \mathrm{~mL}$ of fresh saline and washed four times. The first specimen piece was put in $0.5 \mathrm{~mL}$ saline and the second (gentamicin pretreated) in $0.5 \mathrm{~mL}$ of distilled water, and mixed for 30 minutes. The supernatant from both pieces was placed on MacConkey agar plates and incubated at $37^{\circ} \mathrm{C}$ for 24 and 48 hours. The third piece was used as a negative control and put in $0.5 \mathrm{~mL}$ distilled water and mixed for 30 minutes, then washed four times and put in physiological saline with gentamicin for 30 minutes $-0.5 \mathrm{~mL}$ supernatant was then put on MacConkey agar plates and incubated at $37^{\circ} \mathrm{C}$ for 24 and 48 hours and the number of colonies was counted.

Bacterial identification. The ENTEROtest 24 (Erba Lachema) identified cultivated bacteria using recommended working procedures. This test-kit gives routine identification of important Enterobacteriaceae family species within 24 hours and it provides forty strains identified by 24 biochemical tests. We supplemented identification with paper strip tests: the COLItest detected $E$. coli ( $\beta$-glucuronidase test) and the INDOLtest for O established the organism's ability to convert tryptophan to indole. MALDI-TOF mass spectrometry then confirmed the results and identified bacteria unable to be identified by ENTEROtest.

Statistical analysis. The Pearson Chi-Square test compared differences in bacterial populations in healthy subjects and patients with either adenoma or carcinoma.

\section{Results}

After colonoscope examination, we obtained a set of biopsy samples after colonoscope examination - 10 from patients with colorectal adenoma and 10 from colorectal cancer patients. The patients' characteristics are listed in Table 1. Additional mucosal samples from 9 healthy subjects were taken during preventive colonoscopy examination and these served as controls.

A total of 90 biopsy specimens from 29 individuals were tested by gentamicin protection assay to differentiate between bacterial intra- and extracellular location (Table 2). Two biopsy specimens were tested from each asymptomatic (healthy) subject, and four or six from adenoma and carcinoma patients. After GPA, growth of more than five colonies on MacConkey agar was considered positive. In the fourth biopsy wash, specimens from healthy subjects and patients with adenomas and carcinomas returned $822 \pm 1333$, $2600 \pm 2430$ and $3019 \pm 2114$ colonies, respectively. In contrast,

Table 1. Patient characteristics.

\begin{tabular}{llccc}
\hline \multicolumn{2}{l}{ Characteristic } & $\begin{array}{l}\text { Healthy } \\
\text { controls }\end{array}$ & Adenoma & Carcinoma \\
\hline Individuals & total number & 9 & 10 & 10 \\
& $\begin{array}{l}\text { ratio of } \\
\text { females to males }\end{array}$ & $4 / 5$ & $5 / 5$ & $2 / 8$ \\
Age, years & median & 62 & 59 & 68 \\
\multirow{5}{*}{ Tumor } & range & $28-82$ & $36-72$ & $57-79$ \\
localization & rectum & - & 4 & 5 \\
& sigmoid colon & - & 2 & 3 \\
& descending colon & - & 2 & - \\
& splenic flexure & - & - & 1 \\
& transverse colon & - & 1 & - \\
& hepatic flexure & - & - & 1 \\
& ascending colon & - & 4 & - \\
& cecum & - & 1 & - \\
\hline & multiple tumors & - & 4 &
\end{tabular}


the number of colonies in the healthy subjects after GPA were lowered to less than one, but remained at $29.4 \pm 37.9$ and $153.4 \pm 198.42$ in the adenoma and carcinoma groups.

Overall, the set of specimens were split into 3 groups. Group 1 for controls; healthy subjects who underwent routine colonoscopy; Group 2 for patients with colorectal adenomas and Group 3 for those with colorectal carcinomas. We analyzed both bacteria isolated from colonies grown after GPA and bacteria isolated from colonies in the fourth biopsy wash.

Group 1: here we detected no intracellular bacteria after GPA (Table 3); and $75.8 \%$ of all the bacteria isolated from colonies in the fourth biopsy wash were Escherichia coli. The next bacteria identified were Pseudomonas aeruginosa (13.6\%) and Bacillus cereus (10.6\%).

Group 2: In addition to Pseudomonas aeruginosa and Bacillus cereus, we found Klebsiella pneumoniae (1.4\%) and Enterococcus faecalis (2.5\%) after the fourth biopsy wash. Moreover, Proteus mirabilis was detected in the same quantities both inside and outside the epithelial cells (7.6\%).

Group 3: here we recorded the highest presence of intracellular E. coli (39.4\%). Proteus vulgaris was also located intracellularly in this group, but in very small quantity $(1.2 \%)$. Pseudomonas aeruginosa (6.7\%), Enterococcus faecalis ( $0.6 \%)$ and Klebsiella pneumoniae (0.6\%) were identified in this carcinoma group after the fourth biopsy wash,

Pearson Chi-Square evaluated the difference in bacterial populations in our three groups. Groups 2 and 3 had

Table 2. Results of Gentamicin Protection Assay (GPA) in adenomas and carcinomas vs. healthy mucosa samples.

\begin{tabular}{|c|c|c|c|c|}
\hline \multicolumn{2}{|c|}{ Characteristic } & \multirow{2}{*}{$\begin{array}{c}\text { Healthy } \\
\text { controls }\end{array}$} & \multirow{2}{*}{$\begin{array}{c}\text { Adenoma } \\
10\end{array}$} & \multirow{2}{*}{$\frac{\text { Carcinoma }}{10}$} \\
\hline Individuals & total number & & & \\
\hline & $\begin{array}{l}\text { with positive } \\
\text { GPA }\end{array}$ & 0 & 6 & 8 \\
\hline \multicolumn{2}{|c|}{ Total number of biopsies } & 18 & 36 & 36 \\
\hline \multicolumn{2}{|c|}{$\%$ of GPA positive biopsies } & 0 & 25 & 70 \\
\hline \multicolumn{2}{|c|}{$\begin{array}{l}\text { Mean no. } \pm \text { SD of colonies } \\
\text { grown after GPA }\end{array}$} & $0.44 \pm 0.73$ & $29.4 \pm 37.9$ & $153.4 \pm 198.42$ \\
\hline \multicolumn{2}{|c|}{$\begin{array}{l}\text { Mean no. } \pm \text { SD of colonies in } \\
\text { the fourth biopsy wash }\end{array}$} & $822 \pm 1333$ & $2600 \pm 2430$ & $3019 \pm 2114$ \\
\hline
\end{tabular}

marked increase in the relative abundance of intracellular $E$. coli compared to Group 1 controls. While the difference for these groups was statistically significant $(\mathrm{p}=0.002)$, it was not significant for other bacterial species.

\section{Discussion}

Colon cancer results from accumulated epigenetic and/or genetic mutations in colonic epithelial cells; as first proposed by Fearon and Vogelstein [16]. Mutations in the adenomatous polyposis coli (APC) gene play a pivotal role in the adenomacarcinoma pathway.

Although APC became one of the most frequently mutated known driver genes in colorectal cancer within 25 years of its initial cloning [17], the triggers leading to the genetic progression which culminates in colon cancer have not been defined. It is estimated that clinical colon cancer emerges after a 20- to 40 -year span in which sufficient colonic epithelial cell mutations have accumulated to allow oncogenic transformations to occur. The hypothesis that intestinal bacteria play a key role in carcinogenesis emerged in the early 1970's [18]. An imbalance of microbiota in favor of opportunistic pathogens contributes to higher mucosa permeability, bacterial translocation and the activation of components of both the innate and adaptive immune systems; thus resulting in chronic inflammation [19]. The major consequences of the inflammatory response to commensal bacteria are; (1) activation of transcription factors of specific key cellular signaling pathways in epithelial cells; (2) generation of reactive oxygen and nitrogen species leading to oxidative stress; (3) DNA damage; (4) aberrant proliferation and (5) finally the development of colorectal adenomas and cancer [20].

The presence of intracellularly localized bacteria in adenoma and carcinoma samples was detected on our agar plates after treatment with gentamicin. E. coli account for $83 \%$ of all identified bacteria; and internalized bacteria were protected against antibiotic effects. Our results showed differences in the presence of intracellular E. coli in patients' biopsies compared to healthy mucosa samples. We detected an increasing trend in biopsies, where intracellular E. coli was $0 \%$ in control Group 1, 19.6\% in adenoma Group 2 and

Table 3. Prevalence of bacterial species isolated from biopsy specimens.

\begin{tabular}{|c|c|c|c|c|c|c|}
\hline \multirow{2}{*}{ Bacterial species } & \multicolumn{2}{|c|}{ Group1 (controls) } & \multicolumn{2}{|c|}{ Group2 (adenomas) } & \multicolumn{2}{|c|}{ Group3 (carcinomas) } \\
\hline & GPA + ${ }^{*}$ & GPA - & GPA + & GPA - & GPA + & GPA - \\
\hline Escherichia coli & - & $75.8 \%$ & $19.6 \%$ & $60.1 \%$ & $39.4 \%$ & $51.5 \%$ \\
\hline Klebsiella pneumoniae & - & - & - & $1.4 \%$ & - & $0.6 \%$ \\
\hline Proteus mirabilis & - & - & $7.6 \%$ & $7.6 \%$ & - & - \\
\hline Proteus vulgaris & - & & - & - & $1.2 \%$ & - \\
\hline Pseudomonas aeruginosa & - & $13.6 \%$ & - & $0.6 \%$ & - & $6.7 \%$ \\
\hline Enterococcus faecalis & - & - & - & $2.5 \%$ & - & $0.6 \%$ \\
\hline Bacillus cereus & - & $10.6 \%$ & - & $0.6 \%$ & - & - \\
\hline
\end{tabular}

* GPA + means bacteria isolated from colonies grown after GPA and GPA - means bacteria isolated from colonies in the fourth biopsy wash. 
$39.4 \%$ in carcinoma Group 3. These differences were statistically significant at $\mathrm{p}=0.002$.

The highest number of intracellular bacteria, all identified as E.coli, was detected in a patient with splenic flexure carcinoma. The incidence of this CRC type is very low and has been reported in only 2 to $8 \%$ of total colonic cancers [21]. A direct link between $E$. coli and carcinogenesis or cancer progression has not been reported, but certain commensal E. coli strains encode a genotoxin called colibactin directly in the colon, and this causes double-strand breaks in colon cell DNA [22]. These DNA lesions result in the accumulation of chromosomal anomalies and thus mutations leading to tumorigenesis [23]. Although E. coli is a bacterial driver [12], it is out-competed by commensal bacteria during disease progression [4], and in addition, the high concentration of intracellular bacteria may be due to compromised host immunity which leads to mucosal invasion and to the expression of abnormal surface antigens which promote bacterial adhesion in cancer patients [24].

The next bacteria identified were $P$. mirabilis, $P$. aeruginosa, $K$. pneumoniae, E. faecalis, B. cereus and $P$. vulgaris. We found all these bacteria in different quantities in each group in our study, but due to the low percentage of occurrence in our biopsy samples, these Group differences in bacterial populations were not statistically significant. While we suspect that the occurrence of these species is part of the common gut flora of these patients, all these bacteria are opportunistic pathogens with different virulence factors. For example, $P$. aeruginosa has individual virulence factors that can damage epithelial cells $[25,26]$.

In addition, the Type III Secretion System enables injection of the ExoS effector protein which can assist penetration through the intestinal epithelial barrier by impairing tight junction defense against bacterial penetration [27]. This then promotes systemic inflammation during host stress [28]. Further, E. faecalis induces aneuploidy in colonic epithelial cells [29]. In addition to E. coli, we also detected intracellular localized $P$. mirabilis in adenoma biopsies and $P$. vulgaris in carcinomas, but none of these Proteus species were noted in healthy mucosal samples. An important virulence factor of P. mirabilis is its ability to form a biofilm which protects bacteria from host defenses and decreases antibiotic and antibody penetration $[30,31]$. While it has been demonstrated that bacterial biofilms are associated with CRC [32], Zhang et al. showed that $P$. mirabilis can suppress primary tumor growth and pulmonary metastasis in mouse breast cancer models [33]. Bacterial species mentioned above can trigger cell death and anticancer effects; presumably by recruiting inflammatory cells.

\section{Conclusion}

Due to the complexity of the current disease model used for colon carcinogenesis, it is not possible to establish a conclusive link between colon carcinogenesis and a single bacterium or bacterial function, but future microflora modification presents possibilities in the prevention and even treatment of gastrointestinal cancers [34]. Research in this field should lead to the discovery of innovative therapeutic interventions that decrease colorectal cancer incidence. These include selective removal of potential CRC-driving bacteria and/or the stimulation of health-promoting bacteria before CRC is initiated. The exclusion of opportunistic pathogens by commensal bacteria can also provide natural defense against gastrointestinal diseases, including $\mathrm{CRC}$, and the identification of genuine CRC drivers will aid in early diagnosis and pave the way for novel, microbiome based risk assessment tools and screening strategies for CRC.

When deciding whether an individual is at high risk of CRC development, it is necessary not only to identify the organisms present in the indigenous microbiota but also to determine their functional repertoire. Our preliminary data supports $E$. coli's role as a pro-oncogenic pathogen, and in future research we plan to identify the pathogenic genes and genes associated with adhesion of the virulent $E$. coli we have isolated. We will also focus on monitoring the adherent and invasive abilities of cultured bacteria by co-cultivation with colorectal epithelial cell lines and thus determine the changes in the expression of selected genes in these cancerous cells.

Acknowledgements: This article was prepared with the kind support provided by VEGA Grant 2/0099/17.

\section{References}

[1] DE MARTEL C, FERLAY J, FRANCESCHI S, VIGNAT J, BRAY $F$ et al. Global burden of cancers attributable to infections in 2008: a review and synthetic analysis. Lancet Oncol 2012; 13: 607-615. https://doi.org/10.1016/S14702045(12)70137-7

[2] KUPER H, ADAMI HO, TRICHOPOULOS D. Infections as a major preventable cause of human cancer. J Intern Med 2000; 248: 171-183.

[3] CHEN W, LIU F, LING Z, TONG X, XIANG C. Human intestinal lumen and mucosa-associated microbiota in patients with colorectal cancer. PLoS One 2012; 7: e39743. https:// doi.org/10.1371/journal.pone.0039743

[4] GAO Z, GUO B, GAO R, ZHU Q, QIN H. Microbiota disbiosis is associated with colorectal cancer. Front Microbiol 2015; 6: 20. https://doi.org/10.3389/fmicb.2015.00020

[5] BURNS MB, LYNCH J, STARR TK, KNIGHTS D, BLEKHMAN R. Virulence genes are a signature of the microbiome in the colorectal tumor microenvironment. Genome Med 2015; 7: 55. https://doi.org/10.1186/s13073-015-0177-8

[6] MAGGIO-PRICE L, TREUTING P, BIELEFELDT-OHMANN H, SEAMONS A, DRIVDAHL $R$ et al. Bacterial infection of Smad3/Rag2 double-null mice with transforming growth factor-beta dysregulation as a model for studying inflammation-associated colon cancer. Am J Pathol 2009; 174: 317-329. https://doi.org/10.2353/ajpath.2009.080485 
[7] MARTIN HM, CAMPBELL BJ, HART CA, MPOFU C, NAYAR $M$ et al. Enhanced Escherichia coli adherence and invasion in Crohn's disease and colon cancer. Gastroenterology 2004; 127: 80-93.

[8] LEI X, ZHU Y, TOMKINSON A, SUN L. Measurement of DNA mismatch repair activity in live cells. Nucleic Acids Res 2004; 32: e100. https://doi.org/10.1093/nar/gnh098

[9] GRETEN FR, ECKMANN L, GRETEN TF, PARK JM, LI ZW et al. IKKbeta links inflammation and tumorigenesis in a mouse model of colitis-associated cancer. Cell 2004; 118: 285-296. https://doi.org/10.1016/j.cell.2004.07.013

[10] SOBHANI I, AMIOT A, LE BALEUR Y, LEVY M, AURIAULT ML et al. Microbial dysbiosis and colon carcinogenesis: could colon cancer be considered a bacteria-related disease? Therap Adv Gastroenterol 2013; 6: 215-229. https:// doi.org/10.1177/1756283X12473674

[11] MARCHESI JR, DUTILH BE, HALL N, PETERS WH, ROELOFS R et al. Towards the human colorectal cancer microbiome. PLoS One 2011; 6: e20447. https://doi.org/10.1371/ journal.pone.0020447

[12] TJALSMA H, BOLEIJ A, MARCHESI JR, DUTILH BE. A bacterial driver-passenger model for colorectal cancer: beyond the usual suspects. Nat Rev Microbiol 2012; 10: 575582. https://doi.org/10.1038/nrmicro2819

[13] SEARS CL, PARDOLL DM. Perspective: alpha-bugs, their microbial partners, and the link to colon cancer. J Infect Dis 2011; 203: 306-311. https://doi.org/10.1093/jinfdis/jiq061

[14] SANSONETTI PJ. Rupture, invasion and inflammatory destruction of the intestinal barrier by Shigella, making sense of prokaryote-eukaryote cross-talks. Can J Infect Dis Med Microbiol 2006; 17: 117-119.

[15] COSSART P, SANSONETTI PJ. Bacterial invasion: the paradigms of enteroinvasive pathogens. Science 2004; 304: 242 248. https://doi.org/10.1126/science.1090124

[16] FEARON ER, VOGELSTEIN B. A genetic model for colorectal tumorigenesis. Cell 1990; 61: 759-767.

[17] WACHSMANNOVA L, MEGO M, STEVURKOVA V, ZAJAC V, CIERNIKOVA S. Novel strategies for comprehensive mutation screening of the APC gene. Neoplasma 2017; 64: 338-343. https://doi.org/10.4149/neo_2017_303

[18] HILL MJ, DRASAR BS, HAWKSWORTH G, ARIES V, CROWTHER JS et al. Bacteria and aetiology of cancer of large bowel. Lancet 1971; 1: 95-100.

[19] IVANOV K, KOLEV N, TONEV A, NIKOLOVA G, KRASNALIEV Ietal.Comparativeanalysisofprognosticsignificance of molecular markers of apoptosis with clinical stage and tumor differentiation in patients with colorectal cancer: a single institute experience. Hepatogastroenterology 2009; 56:94-98.

[20] NISTAL E, FERNÁNDEZ-FERNÁNDEZ N, VIVAS S, OLCOZ JL. Factors Determining Colorectal Cancer: The Role of the Intestinal Microbiota. Front Oncol 2015; 5: 220. https:// doi.org/10.3389/fonc.2015.00220

[21] BENEDIX F, SCHMIDT U, MROCZKOWSKI P, GASTINGER I, LIPPERT H et al. Colon carcinoma--classification into right and left sided cancer or according to colonic subsite?--Analysis of 29,568 patients. Eur J Surg Oncol 2011; 37: 134-139. https://doi.org/10.1016/j.ejso.2010.12.004
[22] NOUGAYRÈDE JP, HOMBURG S, TAIEB F, BOURY M, BRZUSZKIEWICZ E et al. Escherichia coli induces DNA double-strand breaks in eukaryotic cells. Science 2006; 313: 848-851. https://doi.org/10.1126/science.1127059

[23] CUEVAS-RAMOS G, PETIT CR, MARCQ I, BOURY M, OSWALD E et al. Escherichia coli induces DNA damage in vivo and triggers genomic instability in mammalian cells. Proc Natl Acad Sci U S A 2010; 107: 11537-11542. https:// doi.org/10.1073/pnas.1001261107

[24] SWIDSINSKI A, KHILKIN M, KERJASCHKI D, SCHREIBER S, ORTNER $M$ et al. Association between intraepithelial Escherichia coli and colorectal cancer. Gastroenterology 1998; 115: 281-286.

[25] SUNDIN C, THELAUS J, BRÖMS JE, FORSBERG A. Polarisation of type III translocation by Pseudomonas aeruginosa requires PcrG, PcrV and PopN. Microb Pathog 2004; 37: 313-322. https://doi.org/10.1016/j.micpath.2004.10.005

[26] MARKOU P, APIDIANAKIS Y. Pathogenesis of intestinal Pseudomonas aeruginosa infection in patients with cancer. Front Cell Infect Microbiol 2014; 3: 115. https://doi. org/10.3389/fcimb.2013.00115

[27] OKUDA J, HAYASHI N, OKAMOTO M, SAWADA S, MINAGAWA $S$ et al. Translocation of Pseudomonas aeruginosa from the intestinal tract is mediated by the binding of ExoS to an Na,K-ATPase regulator, FXYD3. Infect Immun 2010; 78: 4511-4522. https://doi.org/10.1128/IAI.00428-10

[28] SEAL JB, ALVERDY JC, ZABORINA O, AN G. Agent-based dynamic knowledge representation of Pseudomonas aeruginosa virulence activation in the stressed gut: Towards characterizing host-pathogen interactions in gut-derived sepsis. Theor Biol Med Model 2011; 8: 33. https://doi. org/10.1186/1742-4682-8-33

[29] ARTHUR JC, PEREZ-CHANONA E, MÜHLBAUER M, TOMKOVICH S, URONIS JM et al. Intestinal inflammation targets cancer-inducing activity of the microbiota. Science 2012; 338: 120-123. https://doi.org/10.1126/science.1224820

[30] BARTOSZEWICZ M, RYGIEL A. [Biofilm as the basic mechanism of surgical site infection - prevention methods in local treatment]. Chir Pol 2006c 8: 171-178.

[31] CZERWONKA G, GUZY A, KAŁUZA K, GROSICKA M, DANCZUK $M$ et al. The role of Proteus mirabilis cell wall features in biofilm formation. Arch Microbiol 2016; 198: 877-884. https://doi.org/10.1007/s00203-016-1249-x

[32] Dejea CM, Wick EC, Hechenbleikner EM, White JR, Mark Welch JL et al. Microbiota organization is a distinct feature of proximal colorectal cancers. Proc Natl Acad Sci U S A 2014; 111: 18321-18326. https://doi.org/10.1073/pnas.1406199111

[33] ZHANG H, DIAO H, JIA L, YUAN Y, THAMM DH et al. Proteus mirabilis inhibits cancer growth and pulmonary metastasis in a mouse breast cancer model. PLoS One 2017; 12: e0188960. https://doi.org/10.1371/journal.pone.0188960

[34] CIERNIKOVA S, MEGO M, HAINOVA K, ADAMCIKOVA Z, STEVURKOVA $\mathrm{V}$ et al. Modification of microflora imbalance: future directions for prevention and treatment of colorectal cancer? Neoplasma 2015; 62: 345-352. https://doi. org/10.4149/neo_2015_042 